\title{
Is it Possible to Accurately Determine Content of Botulinum Neurotoxin Type A in Drug Products?
}

\section{Dorothea Sesardic}

Division of Bacteriology, National Institute for Biological Standards and Control, Health Protection Agency, South Mimms, Hertfordshire, UK

Botulinum neurotoxin type A (BoNT/A) is the active substance in preparations used both for cosmetic purposes and to treat a variety of neurological disorders. In some preparations, the BoNT/A protein form part of a multi-protein complex. Although the accompanying proteins are considered to play no role in the mechanism of action, their presence has raised concerns regarding the amount of total protein administered, sensitization to the preparation, and the formation of neurotoxin neutralizing antibodies leading to therapeutic failure. Preparations that contain only the BoNT/ A protein could potentially limit the development of such an immune response. Hence, it is important to know how much BoNT/A protein is present.

The article by Dr Jürgen Frevert published in this issue of Drugs in $R \& D^{[1]}$ describes the evaluation of the BoNT/A concentration in three formulations of licensed therapeutic preparations using a sensitive sandwich ELISA assay developed in-house. Only Xeomin ${ }^{\circledR} /$ Bocouture $^{\circledR}$ contains pure BoNT/A protein and is claimed to have the highest purity and specific activity of the formulations tested.

The study is relevant for the characterization of therapeutic preparations of botulinum toxin but is potentially controversial. It is therefore essential that the information presented is correct and is adequately scrutinized. The conclusions of the paper appear to be based on rather limited and variable data, particularly for products other than Xeomin ${ }^{\circledR}$, and should ideally be supported by more focused experimental studies. The claim that the new immunoassay is able to detect only neurotoxin is potentially speculative. It is claimed that antibodies have no ability to detect additional complexing proteins/other clostridial proteins that are known to be present in products other than Xeomin ${ }^{\circledR}$ but no direct evidence of this specificity is directly presented in this paper.

The main argument is that not all toxin A products are of the same purity and that a particular brand may be of lowest specific activity, despite the authors own claim of no difference in clinical use and in laboratory mouse bioassays studies. This assertion is not entirely novel as a previous paper by Ekong et al. ${ }^{[2]}$ reached the same conclusion for the licensed therapeutic toxin A products at that time. The conclusion then was based on the observation of differences in the ratio of immunodetected toxin to their biological activity. The capture antibody ELISA methodology described in the 1995 paper is virtually identical to the method published here. Although particular product brands were not specifically identified in the previous publication, those familiar with these products would have been able to calculate that for Dysport ${ }^{\circledR}$, the toxin A content was approximately $2.0 \mathrm{ng} / 500$ dose that is lethal to $50 \%$ of animals tested $\left(\mathrm{LD}_{50}\right)\left[0.4 \mathrm{ng} / 100 \mathrm{LD}_{50}\right]$, which is lower than the content claimed for this brand and slightly lower than, although comparable to, the value reported by Dr Frevert. ${ }^{[1]}$ It is highly likely that further values will be calculated in other laboratories as the results are both method and reagent specific. It may not be possible to be certain that a 
value determined by Dr Frevert is 'true' until it is verified in another laboratory. Furthermore, unlike the previously published study, the biologic activity was not determined by direct comparison but used information provided by the manufacturer. It is not possible to calculate the specific purity of toxin A in proprietary products from $\mathrm{LD}_{50}$ values provided by the individual manufacturers, unless these values are normalized or standardized. Dr Frevert's conclusions are consistent with other publications on this subject ${ }^{[3-5]}$ that agree the $\mathrm{LD}_{50}$ values indicated on product labels cannot be standardized due to in-house differences in $\mathrm{LD}_{50}$ protocols, which result in differences in the potency and hence bias the calculation of specific activity.

Despite these limitations the sandwich ELISA assay is arguably the best available for the detection of toxin but the suitability of this particular version should be confirmed by other laboratories. In addition, estimation of toxin content in other preparations, including pure neurotoxin formulations, such as in samples reported by Sesardic et al., ${ }^{[5]}$ would be useful, as loss of activity during the production process has been confirmed in bioassays.

\section{Acknowledgments}

No sources of funding were used to prepare this Commentary. The author has no conflicts of interest that are directly relevant to the content of this commentary.

\section{References}

1. Frevert J. Content of botulinum neurotoxin in Botox ${ }^{\circledR /}$ Vistabe ${ }^{\circledR}$, Dysport ${ }^{\circledR} /$ Azzalure $^{\circledR}$, and Xeomin ${ }^{\circledR} /$ Bocouture $^{\circledR}$. Drugs R D 2010; 10 (2): 67-73

2. Ekong TA, McLellan K, Sesardic D. Immunological detection of Clostridium botulinum toxin type $\mathrm{A}$ in therapeutic preparations. J Immunol Methods 1995; 180 (2): 181-91

3. Pickett AM, Hambleton P. Dose standardisation of botulinum toxin. Lancet 1994; 344 (8920): 474-5

4. McLellan K, Das RE, Ekong TA, et al. Therapeutic botulinum type A toxin: factors affecting potency. Toxicon 1996; 34 (9): 975-85

5. Sesardic D, Leung T, Gaines Das R. Role of standards in assays of botulinum toxins: international collaborative study of three preparations of botulinum type A toxin. Biologicals 2003; 31 (4): 265-76

Correspondence: Dorothea Sesardic, Division of Bacteriology, National Institute for Biological Standards and Control, Health Protection Agency, Blanche Lane, South Mimms, Potters Bar, Hertfordshire EN6 3QG, UK.

E-mail: Thea.Sesardic@nibsc.hpa.org.uk 